\title{
PENGARUH KONSENTRASI RAGI TAPE (Saccharomyces cerevisiae) TERHADAP KADAR BIOETANOL PADA PROSES FERMENTASI BIJI ALPUKAT (Persea americana Mill)
}

\section{The Influence of Tape Starter (Saccharomyces cerevisiae) Concentration toward Bioethanol Level in the Fermentation Process of Avocado (Persea americana Mill) Seed}

\author{
*Mohd. Rizwan, Anang Wahid M. Diah, dan Ratman \\ Pendidikan Kimia/FKIP - Universitas Tadulako, Palu - Indonesia 94118 \\ Received 14 September 2018, Revised 18 October 2018, Accepted 11 November 2018
}

\begin{abstract}
Avocado seed contains high level of starch and it can be used as one of the raw materials for bioethanol. This study aimed to determine the influence of variation concentration of tape starter toward bioethanol level in the fermentation process of avocado (persea americana Mill.) seed. Some process on this research were delignification with $4 \% \mathrm{NaOH}$, hydrolysis with $12 \% \mathrm{HCl}$, and fermentation with various concentrations of yeast tape (saccharomyces cerevisiae) ie 10\%, 20\% and 30\% of substrate volume for 5 days. Bioethanol level was determined by using alcoholmeter. The highest bioethanol level was obtained in the addition of yeast tape as much as $30 \%$ of substrate that was an equal to $32.65 \%$ with density of $1.0029 \mathrm{~g} / \mathrm{mL}$.
\end{abstract}

Keywords: Bioethanol, avocado seed, fermentation, tape starter.

\section{Pendahuluan}

Indonesia memiliki iklim tropis yang menyebabkan banyak jenis buah-buahan dapat tumbuh dengan subur. Salah satunya adalah alpukat yang dapat tumbuh pada daerah dengan curah hujan bervariasi dan tidak dapat tumbuh di suhu yang dingin (Muin, dkk., 2014). Produksi buah alpukat di Indonesia pada tahun 2014 adalah sebanyak 307.318 ton dengan luas areal panen 24.200 hektar dan hasil buah rata-rata 12,70 ton/hektar. Tahun sebelumnya produksinya hanya 289.893 ton dengan luas areal panen 22.214 hektar dengan hasil buah rata-rata 13.05 ton/hektar (Pertanian, 2015). Sedangkan produksi buah alpukat di provinsi Sulawesi Tengah pada tahun 2015 adalah sebesar 20,908 buah per hektar dengan jumlah pohon alpukat yang menghasilkan sebanyak 12.994 pohon (BPS, 2015). Berdasarkan data tersebut maka jumlah biji alpukat yang berpotensi menjadi limbah akan berbanding lurus dengan produksi buah alpukatnya. Oleh karena itu, studi tentang pemanfaatan limbah biji alpukat sangat penting untuk dilakukan.

Bagian buah alpukat yang banyak dimanfaatkan adalah dagingnya sedangkan bijinya banyak dibuang dan tidak dimanfaatkan. Hal ini banyak diketahui misalnya dari para pedagang jus buah maupun pasarpasar pedagang buah di Kota Palu.

Biji alpukat memiliki kandungan yang sangat bermanfaat, salah satunya sebagai antioksidan. Hasil analisis fitokimia ekstrak biji alpukat menunjukkan bahwa biji alpukat mengandung polifenol, flavonoid, triterpenoid, kuinon, saponin, tanin, monoterpenoid dan seskuiterpenoid (Leite, dkk., 2009). Selain itu biji alpukat juga memiliki kelembaban 9,92\%, lemak $16,54 \%$, kadar abu $2,40 \%$, protein $17,94 \%$, serat $3,10 \%$ dan karbohidrat 48,11\% (Arukwe, dkk., 2012). Berdasarkan kandungan karbohidratnya yang

${ }^{*}$ Correspondence:

Mohd. Rizwan

Program Studi Pendidikan Kimia, Fakultas Keguruan dan Ilmu Pendidikan, Universitas Tadulako e-mail: mohdrizwan.mr828@gmail.com

Published by Universitas Tadulako 2018 tinggi, maka biji alpukat sangat berpotensi sebagai bahan baku pembuatan bioetanol.

Bioetanol ini dimanfaatkan sebagai bahan campuran bahan bakar bensin di negara-negara maju. $\mathrm{Hal}$ ini sejalan dengan krisis energi dunia yang dihadapi banyak negara termasuk Indonesia. Krisis ini terjadi akibat ketergantungan pemenuhan energi bahan bakar dunia yang berasal dari bahan bakar fosil, padahal bahan bakar ini merupakan sumber daya alam yang tidak dapat diperbaharui dan ketersediannya di dunia sangat terbatas (Haryono, dkk., 2010). Bioetanol dapat juga dijadikan sebagai bahan bakar alternatif yang terbarukan sebagai pengganti batu bara, minyak tanah, elpiji maupun premium.

Beberapa potensi pemanfaatan limbah untuk dikonversi menjadi bioetanol baru-baru ini juga telah dilakukan seperti dari serabut kelapa sawit (Arsyad, dkk., 2015) dan jerami padi (Said, dkk., 2014). Proses pembuatan bioetanol tersebut dilakukan dengan menghidrolisis karbohidrat menggunakan larutan $\mathrm{HCl}$ kemudian dilanjutkan dengan proses fermentasi.

Bioetanol dapat dibuat dari bahan yang mengandung glukosa dengan cara fermentasi. Fermentasi adalah proses terjadinya dekomposisi gula menjadi alkohol dan karbondioksida. Proses fermentasi dimanfaatkan oleh pembuat bir, roti, anggur, bahan kimia dan lain-lain (Muin, dkk., 2014). Contoh produk fermentasi oleh mikroorganisme yang dapat dimanfaatkan antara lain adalah etil alkohol (etanol), asam laktat, asam asetat, gliserol, butilen, glikol, aseton, butanol dan asam butirat (Tarigan, 1990). Salah satu faktor yang dapat mempengaruhi jumlah bioetanol yang dihasilkan dari fermentasi adalah konsentrasi ragi. Jika konsentrasi ragi yang diberikan kurang dari kadar optimal yang disarankan akan menurunkan kecepatan fermentasi karena sedikitnya massa yang akan menguraikan glukosa menjadi etanol, sehingga akan dibutuhkan substrat yang lebih banyak karena substrat yang ada tidak cukup (Winarno, 1992). 
Pembuatan bioetanol menggunakan biji alpukat lebih terfokus pada penggunaan metode hidrolisis menggunakan $\mathrm{H}_{2} \mathrm{SO}_{4}$ seperti yang telah dilakukan oleh Muin, dkk. (2014) yang hasil penelitiannya menunjukkan bahwa kadar etanol tertinggi diperoleh pada metode hidrolisis menggunakan $\mathrm{H}_{2} \mathrm{SO}_{4}$ dengan konsentrasi $6 \%$ dan waktu fermentasi selama 120 jam yaitu sebesar $15,100 \%$. Penggunaan jenis asam yang lain seperti $\mathrm{HCl}$ untuk proses hidrolisis sudah pernah dilakukan oleh Putri \& Supartono (2015) yang memanfaatkan limbah tandan kelapa serta Said, dkk. (2014) yang memanfaatkan jerami padi untuk pembuatan bioetanol. Menurut Erna (2016) dan Arsyad, dkk. (2015) bahwa metode hidrolisis menggunakan $\mathrm{HCl}$ lebih baik dibandingkan dengan $\mathrm{H}_{2} \mathrm{SO}_{4}$. Hal ini terlihat dengan kadar glukosa yang tinggi setelah karbohidrat dihidrolisis dengan menggunakan $\mathrm{HCl}$. Selain itu, penentuan pengaruh konsentrasi ragi tape (saccharomyces cerevisiae) yang menghasilkan jumlah etanol yang lebih banyak juga sudah pernah dilakukan oleh Novia, dkk. (2014) yang meneliti pembuatan bioetanol dari jerami padi.

Artikel ini mengkaji tentang pembuatan bioetanol dari limbah biji buah alpukat dengan memvariasikan konsentrasi ragi tape dalam proses fermentasinya. Hidrolisis yang dilakukan dengan menggunakan larutan $\mathrm{HCl}$.

\section{Metode}

Peralatan yang digunakan antara lain adalah alatalat gelas, alkoholmeter, $\mathrm{pH}$ meter, seperangkat alat evaporator (SB-1100CE), ayakan 50 mesh, autoklaf, oven, piknometer, stopwatch, pompa vakum, spatula, dan neraca digital. Bahan-bahan yang digunakan antara lain adalah biji alpukat, larutan $\mathrm{NaOH}$ (Merck) $4 \mathrm{M}$ dan 4\%, larutan $\mathrm{HCl}$ (Merck) 12\%, ragi tape (saccharomyces cerevisiae), ammonium sulfat (Merck), urea (Merck), aquades, aluminium foil dan kertas saring.

500 gram biji alpukat yang bersih dipotong kecil-kecil $\pm 1 \mathrm{~cm}$. Selanjutnya diblender sampai halus dan dikeringkan dalam oven pada suhu $100{ }^{\circ} \mathrm{C}$ selama 24 jam. Selanjutnya diayak dengan ayakan 50 mesh (Putri \& Supartono, 2015).

\section{Tahap delignifikasi}

Pretreatment atau delignifikasi dilakukan dengan mengambil 100 gram serbuk biji alpukat kemudian ditambahkan $500 \mathrm{~mL} \quad \mathrm{NaOH} \quad 4 \%$ ke dalam Erlenmeyer (Ningsih, dkk., 2012). Campuran kemudian dipanaskan dan diaduk dengan magnetik stirrer selama 2,5 jam pada suhu $80{ }^{\circ} \mathrm{C}$ dan ditutup dengan aluminium foil. Campuran selanjutnya disaring dan dibilas dengan aquades panas $\left(100{ }^{\circ} \mathrm{C}\right)$, kemudian dioven pada suhu $100{ }^{\circ} \mathrm{C}$ selama 24 jam sehingga diperoleh serbuk biji alpukat yang tidak mengandung lignin (Ariyani, dkk., 2013).

\section{Tahap hidrolisis}

20 gram serbuk biji alpukat hasil proses delignifikasi selanjutnya dimasukkan ke dalam Erlenmeyer $1000 \mathrm{~mL}$ dan ditambahkan aquades 200
mL, larutan $\mathrm{HCl}$ 12\% $250 \mathrm{~mL}$, diaduk, dan ditutup dengan aluminium foil. Selanjutnya dipanaskan pada suhu $90^{\circ} \mathrm{C}$ selama 30 menit dan diaduk menggunakan magnetik stirrer (Putri \& Supartono, 2015). Larutan disaring menggunakan kertas saring sehingga diperoleh filtrat dan residu.

\section{Pembuatan starter}

$200 \mathrm{~mL}$ filtrat hasil proses hidrolisis selanjutnya ditambahkan larutan $\mathrm{NaOH} 4 \mathrm{M}$ hingga $\mathrm{pH}$-nya menjadi 5. Selanjutnya dipasteurisasi pada suhu 120 ${ }^{\circ} \mathrm{C}$ selama 15 menit (Seftian, dkk., 2012). Tujuan pasteurisasi pada suhu tersebut adalah untuk mensterilkan bahan agar tidak ada mikroorganisme lain yang hidup sebagai pengganggu dan didiamkan sampai dingin. Setelah itu, $90 \mathrm{~mL}$ filtrat hasil pasteurisasi ditambahkan 6 gram ammonium sulfat dan 6 gram urea sebagai sumber nutrisi (Ariyani, dkk., 2013). Larutan kemudian dibagi menjadi 3 bagian ke dalam Erlenmeyer $250 \mathrm{~mL}$ masing-masing $30 \mathrm{~mL}$, dan ditambahkan ragi tape masing-masing larutan 10, 20 dan 30\% dari volume substrat. Selanjutnya dilakukan inkubasi dengan cara menutup rapat Erlenmeyer, dan selang disambungkan dari Erlenmeyer ke wadah yang berisi air pada suhu berkisar antara $27-30{ }^{\circ} \mathrm{C}$ selama 3 hari serta diberi label starter 1, 2 dan 3 .

\section{Tahap fermentasi}

$90 \mathrm{~mL}$ filtrat sisa hasil pasteurisasi dibagi ke dalam 3 buah Erlenmeyer. Setelah itu untuk Erlenmeyer A ditambahkan dengan starter 1, Erlenmeyer B ditambahkan dengan starter 2, dan untuk Erlenmeyer C ditambahkan dengan starter 3 . Selanjutnya ketiga Erlenmeyer hasil campuran tersebut ditutup dengan aluminium foil kemudian dilakukan pendiaman selama 120 jam (Muin, dkk., 2014).

\section{Tahap pemisahan}

Setelah ketiga Erlenmeyer A, B dan C difermentasi selama 120 jam, selanjutnya masingmasing Erlenmeyer disaring menggunakan pompa vakum dan diambil filtratnya. Filtrat yang diperoleh selanjutnya dimasukkan ke dalam alat evaporator untuk mendapatkan etanol yang diinginkan. Pemisahan dilakukan dengan menggunakan rangkaian alat evaporator dan diatur suhunya pada $60{ }^{\circ} \mathrm{C}$.

\section{Penentuan berat jenis}

Masing-masing etanol yang diperoleh dari hasil evaporasi ditentukan berat jenisnya menggunakan piknometer (Voigt, 1995):

$$
\mathrm{d}=\frac{d_{o} \mathrm{~W}-\mathrm{W}_{\mathrm{e}}}{\mathrm{W}_{\mathrm{o}}-\mathrm{W}_{\mathrm{e}}}
$$

dimana We adalah massa piknometer kosong (g); d adalah berat jenis etanol; $W_{o}$ adalah massa piknometer+aquades (g); W adalah massa piknometer+etanol $(\mathrm{g})$ dan $\mathrm{d}_{\mathrm{o}}$ adalah berat jenis air (1 $\operatorname{gram} / \mathrm{mL}$ ). 


\section{Penentuan kadar etanol}

Setelah ketiga larutan tersebut didistilasi maka masing-masing destilat dimasukkan ke dalam gelas ukur dan diukur kadarnya dengan alkoholmeter.

\section{Hasil dan Pembahasan}

Biji alpukat mengandung karbohidrat khususnya adalah pati. Kandungan pati dalam 100 gram biji alpukat yaitu sebesar $21,3 \%$ sehingga biji alpukat sangat berpotensi sebagai sumber bahan bakar nabati yaitu bioetanol. Produksi bioethanol dari tanaman yang mengandung pati atau karbohidrat dilakukan melalui proses konversi karbohidrat menjadi glukosa dengan menggunakan metode hidrolisis asam kemudian difermentasi sehingga terbentuk bioetanol.

Tahap awal dalam penelitian ini yaitu penyiapan awal sampel biji alpukat yang dipotong kecil-kecil $\pm 1 \mathrm{~cm}$ dengan tujuan untuk memudahkan dalam proses penghalusan dengan blender. Setelah diblender sampai halus selanjutnya dikeringkan dalam oven menggunakan suhu $100^{\circ} \mathrm{C}$ selama 24 jam sehingga diperoleh serbuk biji alpukat yang kering. Penggunaan suhu tersebut bertujuan untuk menghilangkan kadar air yang terkandung dalam biji alpukat. Hal ini terlihat dengan berkurangnya massa dari 500 gram menjadi 224,28 gram setelah pengeringan seperti ditunjukkan pada Tabel 1 .

Tabel 1. Berat serbuk biji alpukat setelah pengeringan dan delignifikasi

\begin{tabular}{llll}
\hline No & Perlakuan & $\begin{array}{l}\text { Berat } \\
\text { Awal (gram) }\end{array}$ & $\begin{array}{l}\text { Berat } \\
\text { Akhir (gram) }\end{array}$ \\
\hline 1 & Pengeringan & 500 & 244,28 \\
2 & Delignifikasi & 100 & 21,63
\end{tabular}

Delignifikasi merupakan proses pembebasan senyawa lignin dalam bentuk senyawa kompleks. Proses ini sangat penting dilakukan karena senyawa lignin merupakan dinding yang kokoh melekat pada selulosa. Apabila tidak dilakukan delignifikasi terlebih dahulu maka karbohidrat akan sulit untuk dihidrolisis menjadi glukosa karena lignin sangat kuat melindungi struktur karbohidrat dan menghambat pertumbuhan mikroba dalam proses fermentasi. Proses delignifikasi dilakukan dengan larutan $\mathrm{NaOH}$ karena larutan ini dapat menyerang dan merusak struktur lignin. Penggunaan larutan $\mathrm{NaOH}$ encer mampu mendegradasi lignin yang melindungi struktur karbohidrat sehingga karbohidrat akan mudah dihidrolisis menjadi glukosa yang dapat difermentasi menjadi bioetanol (Putri \& Supartono, 2015).

Proses delignifikasi dalam penelitian ini menggunakan larutan $\mathrm{NaOH} 4 \%$. Hal ini berdasarkan penelitian yang dilakukan oleh Ningsih, dkk. (2012) yang mengemukakan bahwa larutan $\mathrm{NaOH}$ dapat merusak struktur lignin. Dalam proses delignifikasi dilakukan penyaringan kemudian dibilas dengan aquades panas $\left(100{ }^{\circ} \mathrm{C}\right)$. Tujuan dibilas menggunakan aquades panas yaitu untuk menetralkan sampai $\mathrm{pH} 7$ dan warna filtrat yang dihasilkan berwarna hitam. Selanjutnya dioven menggunakan suhu $100^{\circ} \mathrm{C}$ selama 24 jam.

Berdasarkan filtrat berwarna hitam yang diperoleh setelah penyaringan dapat diketahui bahwa filtrat tersebut merupakan lignin yang sebelumnya terkandung dalam biji alpukat. Serbuk biji alpukat yang tidak mengandung lignin dapat dilihat perubahan warna dari coklat muda menjadi coklat kehitaman. Selain itu beratnya juga mengalami penurunan dari 100 gram menjadi 21,63 gram seperti ditunjukkan pada tabel Tabel 1. Ariyani, dkk. (2013) mengemukakan bahwa berat sampel yang mengalami penurunan menunjukkan adanya lignin yang terlarut setelah dilakukan proses delignifikasi. Biji alpukat belum diketahui apakah mengandung selulosa dan senyawa lignin atau tidak. Oleh karena itu karbohidrat yang terdapat dalam biji alpukat perlu didelignifikasi terlebih dahulu sebelum dilakukan tahap hidrolisis.

Serbuk biji alpukat hasil proses delignifikasi yaitu sebanyak 21,63 gram kemudian ditimbang sebanyak 20 gram dan selanjutnya dihidrolisis menggunakan larutan asam sebagai katalis yang bertujuan untuk mengubah polisakarida (pati) menjadi monosakarida (glukosa). Prinsip hidrolisis pati adalah pemutusan rantai polimer pati menjadi unit-unit dekstrosa atau monosakarida yaitu glukosa $\left(\mathrm{C}_{6} \mathrm{H}_{12} \mathrm{O}_{6}\right)$ (Assegaf, 2009). Penelitian ini menggunakan larutan $\mathrm{HCl}$ 12\% $250 \mathrm{~mL}$ kemudian ditutup menggunakan aluminium foil dan dipanaskan pada suhu $90^{\circ} \mathrm{C}$ selama 30 menit yang bertujuan untuk mempercepat reaksi serta diaduk menggunakan magnetik stirer kemudian disaring menggunakan kertas saring sehingga diperoleh filtrat dan residu, warna filtrat yang terbentuk coklat pekat sehingga menunjukkan bahwa karbohidrat dalam hal ini adalah pati terhidrolisis membentuk glukosa (Putri \& Supartono, 2015).

Mekanisme reaksi yang terjadi pada proses hidrolisis dimulai dari proton dari asam akan berinteraksi secara cepat dengan ikatan glikosidik oksigen pada dua unit gula sehingga akan membentuk asam konjugasi. Keberadaan asam konjugasi menyebabkan konformasi tidak stabil sehingga terjadi pemutusan ikatan $\mathrm{C}-\mathrm{O}$ dan membebaskan asam konjugasi pada konformasi yang tidak stabil. Keberadaan air pada sistem akan menyebabkan ion $\mathrm{OH}^{-}$dari air berikatan dengan ion karbonium sehingga membebaskan gula dan proton. Proton yang terbentuk akan berinteraksi secara cepat dengan ikatan glikosidik oksigen pada dua unit gula yang lain. Proses tersebut terjadi secara kontinyu sampai semua molekul pati terhidrolisis menjadi glukosa (Xiang, dkk., 2003).

Hidrolisis asam baik dilakukan dalam waktu retensi singkat (misalnya 5 menit) pada suhu tinggi (misalnya $180{ }^{\circ} \mathrm{C}$ ) atau dalam waktu retensi relatif lama (misalnya 30-90 menit) pada suhu yang lebih rendah (misalnya $90{ }^{\circ} \mathrm{C}$ ). Kelemahan utama dari beberapa metode hidrolisis, terutama pada $\mathrm{pH}$ rendah adalah pembentukan berbagai jenis inhibitor seperti asam karboksilat, furan dan senyawa fenolik. Bahan 
kimia ini tidak dapat mempengaruhi hidrolisis enzimatik, tetapi mereka biasanya menghambat pertumbuhan mikroba dan fermentasi, yang menyebabkan kurangnya produktivitas etanol. Oleh karena itu, perlakuan awal pada $\mathrm{pH}$ rendah harus dipilih dengan benar untuk menghindari atau setidaknya mengurangi pembentukan inhibitor ini (Taherzadeh \& Karimi, 2008).

Sebanyak $200 \mathrm{~mL}$ filtrat yang diperoleh dari hidrolisis selanjutnya ditambahkan larutan $\mathrm{NaOH} 4$ $\mathrm{M}$ sampai pHnya menjadi 5. Penggunaan $\mathrm{pH} 5$ berdasarkan kondisi optimum pertumbuhan mikroba dalam proses fermentasi. Mikroba tersebut tidak dapat hidup pada kondisi basa (Putri \& Supartono, 2015). Setelah itu dipasteurisasi dengan autoklaf pada suhu $121{ }^{\circ} \mathrm{C}$ selama 15 menit untuk mensterilkan bahan agar tidak ada mikroorganisme lain yang hidup sebagai penganggu. Campuran kemudian perlu didiamkan sampai dingin setelah proses pasteurisasi (Seftian, dkk., 2012). Selanjutnya sebanyak $90 \mathrm{~mL}$ filtrat hasil pasteurisasi digunakan dalam pembuatan starter kemudian ditambahkan amonium sulfat dan urea dengan perbandingan 1:1 yaitu 6 gram amonium sulfat dan 6 gram urea. Campuran tersebut kemudian dibagi menjadi 3 bagian ke dalam Erlenmeyer. Selanjutnya ditambahkan ragi tape masing-masing erlenmeyer sebanyak 10\%, 20\% dan $30 \%$ dari volume substrat. Setiawati, dkk. (2013) mengemukakan bahwa jumlah ragi yang ditambahkan dalam proses fermentasi berpengaruh terhadap bioetanol yang dihasilkan. Kemudian dilakukan inkubasi selama 3 hari sehingga diperoleh starter 1, 2 dan 3 dengan penambahan ragi tape berturut-turut $10 \%, 20 \%$ dan $30 \%$. Tujuan pembuatan starter sendiri sebagai sumber nutrisi bagi saccharomyces cerevisiae.

Penggunaan ragi tape (saccharomyces cerevisiae) dengan alasan mikroba ini lebih cepat mengkonversi gula menjadi etanol (O'Leary, dkk., 2004). Mikroba saccharomyces cerevisiae dapat mengkonversi gula menjadi etanol karena adanya enzim invertase dan enzim zimase yang dihasilkan oleh mikroba tersebut. Adanya enzim-enzim ini saccharomyces cerevisiae memiliki kemampuan untuk mengkonversi baik gula dari kelompok monosakarida maupun dari kelompok disakarida. Jika gula yang tersedia dalam substrat merupakan gula disakarida, maka enzim invertase akan bekerja menghidrolisis disakarida menjadi monosakarida. Setelah itu, enzim zimase akan mengubah monosakarida tersebut menjadi alkohol dan $\mathrm{CO}_{2}$ (Judoamidjojo, dkk., 1992).

Tahap selanjutnya, sebanyak $90 \mathrm{~mL}$ filtrat yang tersisa dari pasteurisasi dibagi kedalam 3 buah Erlenmeyer masing-masing sebanyak $30 \mathrm{~mL}$ kemudian masing-masing starter yang telah diinkubasi selama 3 hari dicampurkan dengan ketiga Erlenmeyer. Selanjutnya difermentasi selama 120 jam. Penggunaan waktu 120 jam untuk fermentasi berdasarkan penelitian yang dilakukan Muin, dkk. (2014) untuk memperoleh kadar etanol paling tinggi. Selanjutnya disaring dengan pompa vakum sehingga diperoleh filtrat dan residu. Filtrat yang diperoleh dimasukkan ke dalam labu alas bulat dan dievaporasi dengan alat evaporator pada suhu $60^{\circ} \mathrm{C}$ kemudian di ukur volumenya sehingga diperoleh volume bioetanol $27,5 \mathrm{~mL}, 30,0 \mathrm{~mL}$ dan 23,0 $\mathrm{mL}$ dengan konsentrasi ragi tape berturut-turut $10 \%, 20 \%$ dan $30 \%$ seperti ditunjukkan pada Tabel 2.

Tabel 2. Pengaruh konsentrasi ragi tape terhadap volume dan kadar bioetanol

\begin{tabular}{|c|c|c|c|c|}
\hline No & $\begin{array}{l}\text { Konsentrasi } \\
\text { Ragi } \\
\text { Tape }(\% \text { b/v })\end{array}$ & $\begin{array}{l}\text { Volume } \\
\text { Etanol } \\
(\mathrm{mL})\end{array}$ & $\begin{array}{l}\text { Massa Jenis } \\
(\mathrm{gram} / \mathrm{mL})\end{array}$ & $\begin{array}{l}\text { Kadar } \\
\text { Etanol }\end{array}$ \\
\hline 1 & $10 \%$ & 27,5 & 1,0048 & $21,47 \%$ \\
\hline 2 & $20 \%$ & 30,0 & 1,0039 & $24,28 \%$ \\
\hline 3 & $30 \%$ & 23,0 & 1,0029 & $32,65 \%$ \\
\hline
\end{tabular}
pemisahan dengan evaporator selanjutnya dianalisis yang terdiri dari penentuan berat jenis dan penentuan kadar bioetanol. Penentuan berat jenis dapat dilakukan dengan menggunakan alat piknometer, sehingga diperoleh berat jenis untuk variasi konsentrasi ragi tape 10, 20 dan 30\% (\%b/v) masingmasing sebesar 1,0048, 1,0039, dan 1,0029 gram $/ \mathrm{mL}$ (lihat Tabel 2). Berat jenis etanol yang diperoleh berbeda dengan berat jenis etanol yang dikemukakan oleh Setiawati, dkk. (2013) yaitu 0,7983 gram $/ \mathrm{mL}$. Perbedaan ini disebabkan karena ketika proses evaporasi terdapat molekul air yang ikut menguap bersama alkohol.

Sedangkan untuk penentuan kadar bioetanol dilakukan dengan menggunakan alkoholmeter. Menurut Mailool, dkk. (2013), prinsip kerja dari alkoholmeter berdasarkan berat jenis campuran antara alkohol dengan air. Cara pengukurannya yaitu memasukkan alkoholmeter dalam gelas ukur yang panjangnya melebihi alkoholmeter dan dalam gelas ukur tersebut telah berisi cairan etanol yang akan diukur. Alkoholmeter akan tenggelam dan batas cairannya akan menunjukkan berapa kandungan etanol dalam larutan tersebut.

Kadar bioetanol tertinggi diperoleh pada konsentrasi ragi tape $30 \%$ yaitu sebesar 32,65\%, sedangkan untuk konsentrasi ragi tape 20\% sebesar $24,28 \%$ dan untuk konsentrasi ragi tape $10 \%$ sebesar $21,47 \%$. Hal ini sesuai dengan penelitian yang dilakukan Novia, dkk. (2014) bahwa semakin besar konsentrasi ragi tape (saccharomyces cerevisiae) maka semakin tinggi kadar bioetanol yang dihasilkan. Semakin besar konsentrasi ragi maka nutrisi yang diperlukan saccharomyces cerevisiae untuk melewati fase lag (fase adaptasi) semakin menurun dan pada akhirnya saccharomyces cerevisiae mampu dengan cepat memproduksi bioetanol dari gula dan menyebabkan pembentukan kadar bioetanol yang semakin banyak karena pemanfaatan glukosa yang optimal sehingga pada penelitian ini kadar bioetanol tertinggi diperoleh pada konsentrasi ragi tape 30\%. Sedangkan untuk konsentrasi ragi tape 10\% dan 20\% diperoleh kadar bioetanol yang lebih rendah dikarenakan rendahnya populasi awal sehingga gula yang ada hanya sedikit yang dirombak menjadi alkohol. Bila pertumbuhan ragi terhambat maka akan mengakibatkan aktivitas 
dari raginya akan berkurang sehingga enzim yang dihasilkan juga berkurang dan alkohol pun akan berkurang juga. Rendahnya jumlah sel yang tidak sebanding dengan media yang digunakan menyebabkan sel akan mengalami fase lag yang lebih lama (Novia dkk., 2014).

Selain itu juga, suhu merupakan salah satu parameter yang paling penting dalam produksi etanol sejak hidrolisis enzimatik dan tahap fermentasi glukosa. Umumnya suhu fermentasi memiliki pengaruh lebih besar pada tingkat fermentasi, sebab suhu fermentasi meningkatkan laju pertumbuhan serta tingkat kenaikan pembentukan produk. Fermentasi bersifat eksotermik, tingkat panas yang dilepaskan tergantung pada kondisi alam disekitarnya. Oleh karena itu kontrol suhu pada suhu optimum tentu akan meningkatkan produksi etanol (Umamaheswari dkk., 2010). Selama fermentasi $\mathrm{pH}$ yang dihasilkan cenderung asam karena dalam pembentukan etanol, juga terjadi pembentukan asam asetat sebagai produk sampingnya. Peningkatan pembentukan asam asetat terjadi akibat penggunaan etanol sebagai sumber energi bagi saccharomyces cerevisiae saat proses fermentasi berlangsung (Muin dkk., 2015). Sehingga diperoleh kesimpulan bahwa 500 gram sampel biji alpukat menghasilkan bioetanol sebesar 32,65\% dengan konsentrasi ragi tape sebesar $30 \%(\% \mathrm{~b} / \mathrm{v})$.

\section{Kesimpulan}

Terdapat pengaruh variasi konsentrasi ragi tape terhadap kadar bioetanol yang dihasilkan pada proses fermentasi biji alpukat. Semakin besar konsentrasi ragi tape (saccharomyces cerevisiae) maka semakin tinggi kadar bioetanol yang dihasilkan. Kadar bioetanol tertinggi adalah 32,65\% diperoleh pada saat konsentrasi ragi tape $30 \%(\mathrm{~b} / \mathrm{v})$.

\section{Ucapan Terima kasih}

Ucapan terima kasih penulis sampaikan kepada Tasrik laboran laboratorium Fakultas Keguruan dan Ilmu Pendidikan yang telah memberikan bimbingan dan masukan dalam menyelesaikan penelitian ini.

\section{Referensi}

Ariyani, E., Kusumo, E. \& Supartono. (2013). Produksi bioetanol dari jerami padi (Oryza sativa L). Indonesian Journal of Chemical Science, 2(2), 167-172.

Arsyad, Diah, A. W. M. \& Said, I. (2015). Analisis kalor dan sintesis bioetanol dari serabut kelapa sawit sebagai alternatif bahan bakar terbarukan. Jurnal Akademika Kimia, 3(4), 204-209.

Arukwe, U., Amadi, B. A., Duru, M. K. C., Agomuo, E. N., Adindu, E. A., Odika, P. C., Lele, K. C., Egejuru, L. \& Anudike, J. (2012). Chemical composition of persea americana leaf, fruit and seed. International Journal of Recent Research and Applied Studies, 11(2), 346-349.
Assegaf, F. (2009). Prospek produksi bioetanol bonggol pisang (musa paradisca) menggunakan metode hidrolisis asam dan enzimatis. Purwokerto: Universitas Jenderal Soedirman.

BPS. (2015). Sulawesi tengah dalam angka 2015. Sulawesi Tengah: BPS Provinsi Sulawesi Tengah.

Erna, Said, I. \& Abram, P. H. (2016). Bioetanol dari limbah kulit singkong (Manihot esculenta cranz) melalui proses fermentasi. Jurnal Akademika Kimia, 5(3), 121-126.

Haryono, Kurniawan, R., Nurhayani, A. \& Soviyani, D. A. (2010). Pembuatan bioetanol dari bahan berbasis selulosa. Jurnal Institut Teknologi Nasional, 2(4), 1-7.

Judoamidjojo, M., Darwis, A. A. \& Sa'id, E. G. (1992). Teknologi fermentasi. Jakarta: Rajawali Press.

Leite, J. J., Brito, E. H., Cordeiro, R. A., Brilhante, R. S., Sidrim, J. J., Bertini, L. M. \& Morais, S. M. (2009). Chemical composition, toxicity and larvacidal and antifungal activities of persea americana (avocado) seed extracts. Revista da Sociadade Brasileira de Medicina Tropical, 42(2), 110-113.

Mailool, J. C., Molenaar, R., Tooy, D. \& Longdong, I. A. (2013). Produksi Bioetanol dari singkong (manihot utilissima) dengan skala laboratorium. Jurnal Teknik Pertanian, 2(1), 1-11

Muin, R., Hakim, I. \& Febriyansyah, A. (2015). Pengaruh waktu fermentasi dan konsentrasi enzim terhadap kadar bioetanol dalam proses fermentasi nasi aking sebagai substrat organik. Jurnal Teknik Kimia, 21(3), 59-69.

Muin, R., Lestari, D. \& Sari, T. W. (2014). Pengaruh konsentrasi asam sulfat dan waktu fermentasi terhadap kadar bioetanol yang dihasilkan dari biji alpukat. Jurnal Teknik Kimia, 20(4), 1-7.

Ningsih, Y. A., Lubis, K. R. \& Moeksin, R. (2012). Pembuatan bioetanol dari tandan kosong kelapa sawit (TKKS) dengan metode hidrolisis asam dan fermentasi. Jurnal Teknik Kimia, 18(1), 30-34.

Novia, Windarti, A. \& Rosmawati. (2014). Pembuatan bioetanol dari jerami padi dengan metode ozonolisis-simultaneous saccarification and fermentation (SSF). Jurnal Teknik Kimia, 20(1), 38-48.

O'Leary, V. S., Green, R., Sullivan, B. C. \& Holsinger, V. H. (2004). Alcohol production by selected yeast strains in lactase hydrolyzed acid whey. Journal Biotechnology and bioengineering, 19(7), 1019-1035.

Pertanian, K. (2015). Statistik produksi hortikultura tabun 2014. Jakarta: Direktorat Jenderal Hortikultura Kementerian Pertanian.

Putri, E. S. \& Supartono. (2015). Pemanfaatan limbah tandan kelapa untuk pembuatan bioetanol melalui proses hidrolisis dan 
fermentasi. Indonesian Journal of Chemical Science, 4(2), 99-104.

Said, M., Diah, A. W. M. \& Sabang, S. M. (2014). Sintesis bioetanol dari jerami padi (Oryza sativa L) melalui fermentasi. Jurnal Akademika Kimia, 3(4), 178-182.

Seftian, D., Antonius, F. \& Faizal, M. (2012). Pembuatan etanol dari kulit pisang menggunakan metode hidrolisis enzimatik dan fermentasi. Jurnal Teknik Kimia, 18(1), 10-16.

Setiawati, R. D., Sinaga, R. A. \& Dewi, K. T. (2013). Proses pembuatan bioetanol dari kulit pisang kepok. Jurnal Teknik Kimia, 19(1), 9-15.

Taherzadeh, M. J. \& Karimi, K. (2008). Pretreatment of lignocellulosic wastes to improve ethanol and biogas production. International Journal of Moleculer Sciences, 9(9), 1621-1651.
Tarigan, J. (1990). Pengantar mikrobiologi. Jakarta: Departemen Pendidikan.

Umamaheswari, M., Jayakumari, M., Maheswari, K., Subashree, M., Mala, P. \& Sevanthi, T. (2010). bioethanol production from cellulosic material. International Journal of Current Research, 1(1), 005-011.

Voigt, R. (1995). Buku pelajaran teknologi farmasi. Yogyakarta: Universitas Gajah Mada Press.

Winarno, F. G. (1992). Pengantar teknologi pangan. Jakarta: Gramedia.

Xiang, Q., Lee, Y. Y., Pettersson, P. O. \& Torget, R. W. (2003). Heterogeneous aspects of acid hydrolisis of a cellulose. Journal Humana Press, 107(1), 504-514. 